\title{
Rozcestí kritické praxe sociální práce v kontextu institucionalizovaného systému sociálních služeb v České republice Radka Janebová
}

\begin{abstract}
Abstrakt:
Kritická praxe sociální práce je (mimo jiné) reakcí na rozmach ideologie neoliberalismu a jako taková to nemá s přežitím úplně jednoduché. Tento příspěvek je věnován organizacím, jejichž praxi Ize či bylo možné považovat v kontextu České republiky za kritickou. Cílem bude reflektovat u vybraných organizací realizujících kritickou praxi jejich fungování ve vztahu k institucionalizovanému systému sociálních služeb a důsledky, které může začlenění do systému mít pro jejich kritickou praxi. Př́klady fungování vybraných organizací mohou ukazovat, jak jsou postaveni před dilema, zda formalizovat svou existenci, vstoupit do institucionalizovaného systému sociálních služeb a zajistit si relativní finanční stabilitu s rizikem tlaků na utlumování kritické praxe, nebo zůstat deformalizovanými, což s sebou nese finanční nejistotu, avšak zároveň to poskytuje větší svobodu vykonávat kritickou praxi.
\end{abstract}

Klíčová slova: kritická praxe, sociální práce, sociální služby, institucionalizace, deformalizace, neoliberalimus, financování

\section{Úvod}

Cílem článku bude reflektovat u vybraných organizací realizujících kritickou praxi sociální práce v České republice jejich fungování ve vztahu k institucionalizovanému systému sociálních služeb a důsledky, které může začlenění do systému mít pro jejich kritickou praxi. Protože sociální práce se neděje ve vakuu, ale odráží kontexty, ve kterých se odehrává, pokusím se svá zjištění zasadit do jednoho z nejpodstatnějších současných kontextů - a to do dominujícího neoliberálního diskursu. Text je psán z východiska kritického vůči tomuto diskursu - z pozice kritické sociální práce a kritiky neoliberalismu Loïca Wacquanta. Než se dostanu k avizovanému cíli, je vhodné alespoň stručně vyjasnit roli sociální práce v neoliberální společnosti, tak jak je vnímána z kritické pozice, poté vymezit, co rozumím kritickou praxí, a teprve poté mohu formulovat hypotézy o fungování organizací realizujících kritickou praxi v institucionalizovaném systému sociálních služeb a o dopadech tohoto fungování na jejich kritickou praxi. Předložené výstupy je třeba chápat pouze jako hypotézy induktivně vyvozené z výše uvedených článků a ze studia dokumentů (webových stránek a facebookových profilů uvedených organizací a článků vztahujících se k popisovaným 
událostem), přičemž je třeba na začátku textu deklarovat, že znění hypotéz nutně podléhá vlivu deklarované kritické pozice.

\section{Role sociální práce v neoliberální společnosti z kritické pozice}

Sociální práce je logicky ovlivňována kontextem, ze kterého vychází a ve kterém se angažuje. V zemích, které bývají optikou globálních studií označovány jako země bohatého Severu, dochází od 70. let 20. století k sérii událostí, které měly zásadní dopady na ekonomiky národních států a na vývoj sociálních států. Mezi nimi hrály prim válka ve Vietnamu, neudržitelnost dolaru krytého zlatem a následný konec Brettonwoodského systému, jomkipurská válka mezi Izraelem a jeho arabskými sousedy následovaná zvýšením cen ropy. ${ }^{1}$ Následující celosvětová hospodářská stagnace přinesla řadu otázek $\mathrm{k}$ fungování sociálních států. Krizi legitimity do té doby převládajících keynesiánských států usilujících o vyvažování negativních důsledků tržních mechanismů na životy lidí dokázali lépe využít liberálové, kteří s argumentem nepřijatelnosti pokračujících zásahů státu do svobody lidí tlačili vlády k omezování intervencionalismu a prosazování volného trhu a vlastnických práv jako klíčových principů nově fungujících států. ${ }^{2}$ Nastoupilo nové dominantní ideologické paradigma - neoliberalismus, což někteří autoři označují jako tzv. neoliberální revoluci. ${ }^{3}$

Neoliberalismus lze chápat bud' úzce ekonomisticky jako myšlenkový proud činný pouze v oblasti ekonomiky, postavený na předpokladu, že nejvyšší úrovně sociálního blaha celé společnosti bude dosaženo skrze principy individuální odpovědnosti, prosazování principů volného trhu a minimalizace státu. Lze ho také chápat velmi široce ve smyslu Foucaultova konceptu governmentality ${ }^{4}$ jako praxe vládnutí, která v sobě spojuje specifické technologie moci zaměřené na formování mentality subjektů v jejich každodenním fungování. Vzhledem k tomu, že první pojetí je značně zjednodušující, zatímco druhé svou neohraničeností nespecifikuje roli státu, trhu a občanství při ovládání lidí, vymezuje francouzský sociální antropolog a sociolog Loïc Wacquant ještě třetí pojetí neoliberalismu, které nazývá Kentauř́m státem ${ }^{5}$. V něm neoliberalismus neusiluje o demontáž státu, ale chápe ho jako regulátora (nikoliv de-regulátora), který formuje občanství v souladu s požadavky trhu. Tento model je postaven na tezi, že neoliberalismus není ekonomickým, ale politickým projektem partnerství kapitálu se státem. Podobným způsobem vnímá neoliberalismus autor knihy A Brief History of Neoliberalism David Harvey ${ }^{6}$, který ho považuje za politický projekt, který má za cíl udržet na uzdě moc zaměstnanců, jimiž se vládnoucí třída cítí být ohrožena, a zároveň slouží k optimalizaci podmínek pro akumulaci kapitálu a udržení moci ekonomických elit. Prostředkem k dosažení těchto cílů je stát ve službách kapitálu. To je podle obou autorů také důvodem, proč stát stále existuje. Kapitál sám o sobě není schopen vytvářet podmínky pro svou akumulaci, takže potřebuje, aby stát přežil a pracoval v jeho prospěch. Vzhledem k tomu, že stát je hlavním zadavatelem sociální práce, jeví se toto pojetí neoliberalismu z kritické pozice jako optimální východisko pro diskuzi k roli sociální práce v éře neoliberalismu.

Česká republika sice nesdílela se zeměmi bohatého Severu neoliberální revoluci v 70. a 80. letech

Bob MULLALY, The New Structural Social Work, Ontario: Oxford University Press, 2007.

Ian HYSLOP, Neoliberalism and Social Work Identity, European Journal of Social Work 1/2018, s. 20-31.

Petr KRČÁL - Jiří MERTL, Reflexe neoliberalismu v sociální teorii a politické filosofii, in: Neoliberalismus a marginalita, studie z českého reálkapitalismu, ed. Lubomír Lupták a kol, Brno: Doplněk, 2013, s. 7-42.

Michel FOUCAULT, Ethics: Subjectivity and Truth, ed. Paul RABINOW, New York: The New Press, 1997.

5 Loï WACQUANT, Three Steps to a Historical Anthropology of Actually Existing Neoliberalism, Social Anthropology/Anthropologie Sociale 1/2012, s. 66-79.

6 David HARVEY, A Brief History of Neoliberalism, Oxford: Oxford University Press, 2005. 
20. století, ale poměrně bleskově ji prodělala bezprostředně po tzv. Sametové revoluci, když se rozhodla plnit body Washingtonského konsenzu. Tento desetibodový manuál vytvořený Mezinárodním mènovým fondem $\mathrm{v}$ roce 1989 je postaven na návratu ke klasické ekonomii a zcela ignoruje fakt, že problémem vyrovnaných rozpočtů nejsou výdaje, ale př́ijmy. ${ }^{7}$ Když se vláda Václava Klause pod heslem „utahování opaskư inspirovala ve Washingtonskému konsenzu a začala uplatňovat politiku škrtů (oficiálně označovaných jako disciplinovaná fiskální politika), zrušení daňové progrese, prodávání práce pod cenou, nevýhodné liberalizace obchodu vedoucí ke kolonizaci české ekonomiky, vyvlastňování státních podniků pod hlavičkou privatizace a deregulací, ${ }^{8}$ v podstatě tak provedla neoliberální turborevoluci. Protože se škrty z hlediska neoliberální logiky musí primárně vztahovat k omezování funkcí státu - a to zejména v sociální oblasti - realizovala jejich druhou vlnu naplno pravicová vláda Petra Nečase v letech 2010 až 2013. Zásadním důsledkem tzv. Drábkových reforem bylo, že vedly k drastickému sociálnímu propadu těch nejslabších lidí ve společnosti.

Wacquantův ${ }^{9}$ Kentauří stát má dva zásadní úkoly. Za prvé regulovat prostředí k zajištění korporátního profitu a za druhé disciplinovat lidi, a to zejména příslušníky nižších vrstev. Využívá k tomu čtyři politiky. Skrze ekonomickou politiku se snaží komodifikovat oblasti ještě trhem neovládnuté a maximálně osekat výdaje v oblastech, které nepřináší kapitálu finanční zisk. Sociální politiku transformuje z ochranné do nápravné formy, takže pomoc od státu přestává být sociálním právem, jako tomu bylo v keynesiánském kapitalismu, ale je podmiňována poslušností a plněním povinností ke státu. Trestní politika slouží k přesunu lidí, kteří neobstáli před požadavky politiky sociální, do penálního systému. ${ }^{10}$ Také slouží k obnovování ztracené legitimity státu v očích „slušných občanư “, u nichž je nejprve vyvolána morální panika z ohrožení nepřizpůsobivými, aby byli posléze uchlácholeni ráznými zásahy státu vůči těmto lidem na okraji společnosti. Kulturní politika prosazuje ideje individuální odpovědnosti jako motivačního diskursu, který vzájemně tmelí všechny zmíněné politiky státu.

Zásadní dopady těchto politik na sociální práci se projevují v nárůstu chudých (v mezinárodním kontextu viz např. Piketty in Keller $^{11} ; \mathrm{Oxfam}^{12}$; v českém kontextu viz např. Švihlíková ${ }^{13}$; Tožička ${ }^{14}$; Prokop $\left.{ }^{15}\right)$, v osekávání výdajů na služby sociální práce věnované lidem považovaným za nezasluhující - nezaměstnané, tzv. nepřizpůsobivé, lidi bez domova, samoživitelky (data Českého statistického úřadu z roku $2017^{16}$ naznačují, že u tzv. zasluhujících chudých nejsou až takovým problémem škrty, jako spíše dlouhodobé podfinancování systému sociální ochrany) - a v konkurenci mezi službami, která produkuje servilní chování vůči zadavatelům a limituje snahy o prosazování

\footnotetext{
Ilona ŠVIHLÍKOVÁ, Jak jsme se stali kolonií, Praha: Rybka Publishers, 2015.

Tamtéž.

WACQUANT, Three..., s. 66-79.

10 Zatímco původně sloužila trestní politika primárně $\mathrm{k}$ trestu a nápravě lidí páchajících kriminální delikty, v Kentauřím státu se podle Wacquanta stává stále více součástí jeho disciplinární Pravé ruky, která má za úkol zasahovat proti chudým.

11 (c) Jan KELLER, Thomas Piketty: Kapitál ve 21. století (recenze knihy) (on-line), Argument, dostupné na: http://casopisargument. cz/2017/01/31/thomas-piketty-kapital-ve-21-stoleti/, aktualizace dne 31. 1. 2017, citováno dne 2. 3. 2018.

12 C OXFAM INTERNATIONAL, 5 Shocking Facts about Extreme Global Inequality and How to Even It Up (on-line), dostupné na: https://www. oxfam.org/en/even-it/5-shocking-facts-about-extreme-global-inequality-and-how-even-it-davos, aktualizace 2018, citováno dne 2.3. 2018.

13 ŠVIHLÍKOVÁ, Jak...

14 C Tomáš TOŽIČKA, Česká republika je zchudlý stát (on-line), Deník Referendum, dostupné na: http://denikreferendum.cz/clanek/24313ceska-republika-je-zchudly-stat, aktualizace dne 19. 12. 2016, citováno dne 5. 3. 2018.

15 @ Daniel PROKOP, Výzkum chudých (on-line), Praha: Median, dostupné na: http://data.idnes.cz/soubory/domaci/A161114_NEH_009_ CHUDOBA1_MEDIAN.PDF, aktualizace dne 27. 10. 2016, citováno dne 5.3. 2018.

16 ○ ČESKÝ STATISTICKÝ ÚŘAD, Vybrané údaje o sociálním zabezpečení za rok 2016 (on-line), dostupné na: https://www.czso.cz/ documents/10180/46002380/19002917.pdf/30a86875-3361-44c4-ae3c-d3ad502f68fa?version=1.0, aktualizace dne 10. 11. 2017, citováno dne 22. 2. 2018.
} 
práv klientů (viz např. Hloušková ${ }^{17}$; Valová, Janebová18; Janebová a kol. ${ }^{19}$ ). Zdá se tedy, že neoliberalismus může zásadním zpo̊sobem limitovat schopnost či možná ochotu sociální práce prosazovat lidská práva, sociální spravedlnost, bojovat s chudobou a nespravedlností a prosazovat etické imperativy pomoci. ${ }^{20}$ Naopak může vést $\mathrm{k}$ důrazu na kontrolu, vnucování sociálních norem, pacifikaci lidí a jejich disciplinaci (např. Leonard ${ }^{21}$; Day $^{22}$; Mert $^{23}$; Janebová, Truhlářová ${ }^{24}$; Janebová$\left.^{25}\right)$. Stanovisko, že sociální práce vstupuje do služeb neoliberálního státu a stává se stále více jeho ukázňujícím nástrojem, vede některé kritické autory k tomu, že sociální pracovníky označují jako soft cops (např. Day ${ }^{26}$; Messing ${ }^{27}$ ), což lze přeložit jako „hodné policajty“. Na tuto situaci, kdy sociální práce začíná rezignovat na své pomáhající poslání a vstupuje do služeb Kentauřího státu, se pokouší reagovat kritická sociální práce.

\section{Kritická praxe sociální práce v České republice a způisoby její realizace}

Pojem kritická sociální práce zahrnuje celou řadu rozmanitých proudů (strukturalistický, radikální, feministické, antirasistické, transnacionální, postmodernistické, anti-opresivní přístupy atd.), přesto u nich lze nalézt některé společné znaky. Klade důraz na analýzu mocenských mechanismů vedoucích $\mathrm{k}$ nerovnosti a útlaku ve společnosti, na participaci lidí při řešení jejich problémů, na „zplnomocňování lidí ke kolektivním akcím za účelem dosažení sociálních změn a chce stát na straně utlačovaných a bezmocných lidí při dosahování společenských změn. ${ }^{28}$ Příčiny vzniku sociálních problémů vidí ve strukturálních aspektech, jako jsou nespravedlivé či vykořistující společenské uspořádání mezi sociálními vrstvami, gendery, rasami, sexuálními identitami, věkovými skupinami apod. Individuální problémy lidí jsou z pohledu kritické sociální práce vždy determinovány společenským uspořádáním. ${ }^{29}$

Vzhledem k tomu, že v české sociální práci se kritická sociální práce dosud výrazněji neetablovala a nepodařilo se mi dohledat prakticky činné organizace sociální práce, které by se s tímto proudem jasně identifikovaly, využívám označení „kritická praxe“. To se zaměřuje spíše na naplňování znaků kritické praxe než na identifikaci se souborem idejí charakterizujících kritickou sociální práci.

Když jsme s Barborou Celou ${ }^{30}$ hledaly výše uvedené znaky kritické sociální práce v české praxi, nalezly jsme několik organizací a spolků, jejichž činnosti bylo možné za kritickou praxi označit (např. Konexe, Jako doma, Vzájemné soužití, Český západ, ASLIDO, KRISA). Z našeho výzkumu

17 Zuzana HLOUŠKOVÁ, Etické aspekty účasti poskytovatelů v procesech komunitního plánování sociálních služeb, in: Etika sociální práce, ed. Miroslav KAPPL - Martin SMUTEK - Zuzana TRUHLÁŘOVÁ, Hradec Králové: Gaudeamus, 2010, s. 223-228.

18 Hana VALOVÁ - Radka JANEBOVÁ, „Antiradikálnost“ českých sociálních služeb aneb jak organizace sociálních služeb řeší pokles finančních prostředků, Sociální práce / Sociálna práca 1/2015, s. 5-23.

19 Radka JANEBOVÁ - Marcela HUDEČKOVÁ - Romana ZAPADLOVÁ - Jana MUSILOVÁ, Př́běhy sociálních pracovnic a pracovníků, kteří nemlčeli - Popis prožívaných dilemat, Sociální práce / Sociálna práca 4/2013, s. 66-83.

20 Carolyn NOBLE, Postmodern Thinking Where is It Taking Social Work?, Journal of Social Work 3/2004, s. 289-304.

21 Peter LEONARD, The Function of Social Work in Society, in: Talking about Welfare: Readings in Philosophy and Social Policy, ed. Noel W. TIMMS - David WATSON, Boston: Routledge and Kegan Paul, 1976, s. 252-266.

22 Phyllis J. DAY, Social Welfare: Context for Social Control, The Journal of Sociology \& Social Welfare 1/1981, s. 29-44.

23 Jiří MERTL, Přerozdělování welfare. Nátroj pomoci, nebo kontroly?, Brno: Doplněk, 2017.

24 Radka JANEBOVÁ - Zuzana TRUHLÁŘOVÁ, Téma kontroly ve vybraných etických kodexech sociální práce, Caritas et veritas $2 / 2018$, s. 196-209 či Radka JANEBOVÁ, Vybrané principy kritické sociální práce v kontextu kontroly nedobrovolných klientů, Sociální práce / Sociálna práca 3/2018, s. 5-21.

25 Radka JANEBOVÁ, Posedlost sociální práce managementem rizik a rezignace na potřeby, Sociální práce/ Sociálna práca 6/2018, s. 39-56.

26 DAY, Social..

27 Jill T. MESSING, The Social Control of Family Violence, Affilia 2/2011, s. 154-168.

28 Karen HEALY, Reinventing Critical Social Work: Challenges from Practice, Context and Postmodernism, Critical Social Work 1/2001.

29 Jan FOOK, Radical Casework: A Theory of Practice, Sydney, Australia, Allen \& Unwin, 1993.

30 Radka JANEBOVÁ - Barbora CELÁ, Kritická praxe mezi „jinou“ sociální prací a aktivismem, Sociální práce / Sociálna práca 2/2016, s. $22-38$. 
ale také vyplynulo, že tyto aktivity nebyly většinou identifikovaných organizací jako kritická sociální práce deklarovány. Probíhaly bud’ intuitivně bez reflexe vztahu k sociální práci v obecném pojetí či ke kritické sociální práci, nebo se reflektovaně vymezovaly vůči mainstreamové sociální práci a hlásily se $\mathrm{k}$ aktivismu. Aktivity kritické praxe byly propagovány hlavně skrze platformu KRISA (Kritická sociální akce), která svou př́islušnost ke kritické sociální práci otevřeně deklaruje na Facebooku: „Jsme sociální pracovníci, kteří chtějí dělat sociální práci jinak! Širíme kritickou sociální práci - v teorii i praxi."

$\mathrm{V}$ návaznosti na předchozí výzkum ${ }^{31}$ jsem se pokusila rozlišit čtyři zpơsoby realizace kritických principů sociální práce v České republice. Ty vyplynuly z aplikace dvou kritérií (viz Tabulka č. 1). První kritérium zohledňuje, nakolik jsou aktivity splňující znaky kritické sociální práce reflektovány jejími realizátory jako kritická sociální práce. Druhé kritérium sleduje, zda jsou dané aktivity vykonávány v rámci systému či mimo systém (sociálních služeb). Toto kritérium vychází od tvůrce „nové strukturální sociální práce“ Boba Mullalyho ${ }^{32}$, který rozlišil dvě cesty, jak lze dosahovat změn ve společnosti. První umírněnější cesta „uvnitř (a proti) systému“ (working within /and against/ the system) se zaměřuje na poskytování podpory a pomoci lidem znevýhodněným reformou stávajících institucí sociálního státu. Je spojována s intrapsychickou a interpersonální prací postavenou na principech zvyšování vědomí lidí, zplnomocnění a radikalizaci stávajících organizací sociální práce. Druhá radikálnější cesta „mimo systém (a proti systému)“ (working outside /and against/ the system) považuje stávající sociální systém za nereformovatelný, protože nerovnost a oprese jsou jeho integrální součástí. Proto se orientuje na aktivity, které mohou vést ke změně sociálního uspořádání, či na aktivity, které fungují nezávisle na systému sociální ochrany státu (např. zakládání alternativních služeb a organizací, zájmových koalic, sítí a sociálních hnutí, spolupráci s progresivními odbory či snahu o radikalizaci profesních asociací, angažování v politice za progresivní politické subjekty). Hranici mezi „uvnitř“ a „mimo“ systém je třeba chápat jako imaginární či neostrou, protože někdy lze obě strategie od sebe odlišit jen s velkými obtížemi. Zároveň je třeba zdůraznit, že cílem tohoto př́íspěvku není hodnotit adekvátnost či neadekvátnost těchto metod, ale pouze navrhnout souvislost mezi jejich „radikalitou“ a institucionalizací.

\section{Tabulka č. 1: Čtyři způsoby realizace kritické praxe sociální práce v ČR ${ }^{33}$}

\begin{tabular}{|c|c|c|}
\hline Kritéria & $\begin{array}{l}\text { Reflektovaná kritická praxe } \\
\text { sociální práce }\end{array}$ & $\begin{array}{l}\text { Nereflektovaná kritická } \\
\text { praxe sociální práce }\end{array}$ \\
\hline Mimo systém & $\begin{array}{l}\text { Organizace: KRISA, ASLI- } \\
\text { DO } \\
\text { Financování: nezávislé na } \\
\text { státu } \\
\text { Metody: změna systému } \\
\text { (demonstrace, happeningy, } \\
\text { blokády, tvorba sítí, otevře- } \\
\text { né dopisy, zplnomocňování } \\
\text { lidí, jednání s politiky...) }\end{array}$ & $\begin{array}{l}\text { Organizace: Jako doma, } \\
\text { Konexe } \\
\text { Financování: nezávislé na } \\
\text { státu } \\
\text { Metody: změna systému } \\
\text { (demonstrace, happeningy, } \\
\text { blokády, tvorba sítí, otevře- } \\
\text { né dopisy...) }\end{array}$ \\
\hline
\end{tabular}

31 Radka JANEBOVÁ, Reflexe kritické praxe sociální práce v ČR, in: Proměny a príležitosti sociální práce v ČR, Sborník z konference pořádané ke Světovému dni sociální práce, Praha: MPSV, 2017, s. 55-59.

32 MULLALY, The New..., s. 287-363.

33 JANEBOVÁ, Reflexe..., s. 57. 


\begin{tabular}{|c|c|c|}
\hline V rámci systému & $\begin{array}{l}\text { Není mi známa organizace, } \\
\text { která by se takto deklaro- } \\
\text { vala }\end{array}$ & $\begin{array}{l}\text { Organizace: Český západ, } \\
\text { Vzájemné soužití } \\
\text { Financování: může být zá- } \\
\text { vislé i nezávislé na státu } \\
\text { Metody: reforma lidí a stá- } \\
\text { vajících institucí (zvyšování } \\
\text { vědomí lidí, participace na } \\
\text { reformách, jednání s poli- } \\
\text { tiky...) }\end{array}$ \\
\hline
\end{tabular}

Za organizace, které realizují sociální práci spiše nereflektovaně a mimo systém, lze považovat Jako doma, orientující se na zplnomocňování žen bez domova, či Konexe, zaměřené na aktivizaci romských komunit. V obou př́padech se jedná o organizace, které jsou financovány z nadací, fondů a projektů nezávislých na státu. Při prosazování práv lidí užívají metody jako demonstrace, happeningy, otevřené dopisy, blokování ulic, posilování hrdosti, kritický akční výzkum, jednání s politiky apod., tedy běžné metody kritické sociální práce. Tyto organizace se však nedeklarují jako organizace vykonávající kritickou sociální práci. Spíše se považují za organizace aktivistické (více viz Janebová, Celá34). Sociální práci vnímají pouze v jediném diskursu, a to v dominujícím tradičním/konvenčním/mainstreamovém, který je podřízen neoliberální ideologii.

Za organizace, které v rámci systému spiše nereflektovaně prosazují principy kritické sociální práce, lze považovat Český západ a Vzájemné soužití (obě se zaměřují primárně na sociální práci se sociálně vyloučenými). Nereflektovanost vyplývala z neznalosti kritické sociální práce. Jejich financování z větší části pochází z oblasti sociálních služeb. Využívají méně radikální metody kritické sociální práce - zejména metody komunitní práce, staví na principech participace a zplnomocňování lidí, avšak angažují se i v jednáních s politiky (více viz Janebová, Celáa ${ }^{35}$ ). Radikálním akcím se vyhýbají, ovšem níže popsaná zkušenost Vzájemného soužití z roku 2012 ukazuje, že v České republice je verbální kritika města považována za radikální krok, který může být následován sankcemi.

KRISA a ASLIDO (Akční skupina s lidmi bez domova) jsou skupiny, které se reflektovaně hlásí ke kritické sociální práci. Vznikly a fungují spiše mimo systém. Obě jsou založené na dobrovolné bázi. Zatímco KRISA funguje pouze jako platforma na Facebooku, v případně ASLIDO lze dohledat menší finanční podporu ze zahraničních nadací (obě jsou tedy nezávislé na „státu“). Příkladem metod sociální práce může být tvorba informačních materiálů pro lidi bez domova (Mapa bez domova, což je databáze služeb pro lidi bez domova); výzva lidem bez domova, aby hlásili násilí na pražském Hlavním nádraží Policii (oboje KRISA); happening před Poslaneckou sněmovnou jako protest proti stíhání Miloše Neubauera, který na chodníku vytvořil „živou šablonu“ mrtvého člověka bez domova při protestu proti novele zákona o pomoci v hmotné nouzi; či kolektivní akce lidí bez domova, kteř́ chtěli se zástupci Magistrátu města Ostravy jednat o prázdném městském domě v centru Ostravy určenému $\mathrm{k}$ demolici, přestože by mohl sloužit $\mathrm{k}$ sociálnímu bydlení, a následný otevřený dopis témuž Magistrátu, kde byl vyzýván k jednání.

Popis čtyř způsobů realizace kritické praxe vybraných organizací v České republice zatím přiliš nevypověděl o jejich souvislosti s institucionalizací a dopadech na kritičnost jejich aktivit. 


\section{Fungování kritické praxe ve vztahu k institucionalizovanému systému sociálních služeb}

Níže se pokusím popsat fungování zmíněných organizací ve vztahu k institucionalizovanému systému a důsledky, které může začlenění do systému mít pro způsob realizace jejich kritické praxe. Konkrétním systémem je v českém kontextu myšlen systém sociálních služeb. Z Tabulky č. 1 lze vyvodit hypotézu, že organizace, které vykonávají kritickou praxi „v rámci systému“, užívají méně kritické metody (zvyšování vědomí lidí, participace na reformách, jednání s politiky) než organizace „mimo systém“ (demonstrace, happeningy, blokády, tvorba sítí, otevřené dopisy atd.). Zapojení do tohoto systému, které si vynucuje institucionalizaci, může limitovat možnost organizací realizovat některé (radikálnější) kritické metody v situacích, kdy by užití takových metod mohlo být vhodnější v zájmu klientů ${ }^{36}$.

Institucionalizaci lze chápat jako proces rozvoje či transformace pravidel a procedur, které ovlivňují konkrétní soubor lidských interakcí. Jejím záměrem je regulovat společenské chování lidí uvnitř organizací nebo celé společnosti, ${ }^{37}$ čehož je dosahováno transformací neformálních pravidel do strukturovaných a formalizovaných systémů, ${ }^{38}$ které se stávají pro jejich členy závazné, a tedy i sankcionovatelné ${ }^{39}$. Aby organizace realizující kritickou praxi mohly vykonávat své aktivity v rámci systému sociálních služeb, musely projít procesem institucionalizace, protože potřebovaly naplnit požadavky tohoto systému. Z výše uvedené tabulky vyplývá, že do systému sociálních služeb se zapojily Vzájemné soužití a Český západ.

Všechny výše zmíněné organizace původně vznikaly se záměrem aktivně prosazovat práva lidí, které vnímaly jako utlačované či marginalizované - tedy těch, které Kentauří stát považuje za „neoliberální delikventy“ ${ }^{40}$ Mezi ně patří lidé, kteří selhali v neoliberálním imperativu být „dobrými tržními občany“41, lidé, kteří nemají zaměstnání a žádají kvưli tomu stát o sociální pomoc ${ }^{42}$. Zatímco konvenční sociální práce se orientuje na nápravu chování neoliberálních delikventů, na reformu jejich morálky, aby se stali Foucaultovými ${ }^{43}$ homo oeconomicus - tedy podnikateli se sebou samými, či Kellerovými ${ }^{44}$ kapitalisty se svým sociálním kapitálem, znakem kritické praxe je, že tyto lidi vnímá spíše jako oběti nespravedlivého a utlačujícího systému, který s neoliberální rafinovaností přehazuje odpovědnost za své vlastní selhávání na jednotlivce.

\section{Cesta institucionalizace}

Začátky fungování kritických organizací byly do značné míry založeny na dobrovolnické bázi, a to bud' zcela bez finančních zdrojů, nebo s poměrně nízkými prostředky získanými z darů a udělených grantů různých nadací. Některé z nich se s postupným rozrůstáním počtu lidí, kterým pomáhaly, a s nárůstem zaměstnaných spolupracovníků začaly ucházet i o dotace udě-

6 O jaké situace se jedná, je již otázka přesahující cíl tohoto př́spěvku.

37 ○ Hans KEMAN, Institutionalization (on-line), dostupné na: https://www.britannica.com/topic/institutionalization, aktualizace 2018, citováno dne 10. 10. 2018.

38 (C) Merriam-Webster, Institutionalize (on-line), dostupné na: https://www.merriam-webster.com/dictionary/institutionalize, aktualizace 2018, citováno dne 10. 10. 2018.

39 Bohumil GEIST, Sociologický slovník, Praha: Viktoria Publishing, 1992, s. 134.

40 MERTL, Přrozdělování...

41 Mike DEE, Welfare Surveillance, Income Management and New Paternalism in Australia, Surveillance \& Society 3/2013, s. 272-286.

42 MERTL, Přerozdělování...

43 Michel FOUCAULT, Security, Territory, Population. Lectures the Collège de France 1977-1978 (ed. Michel SENELLART), New York: Palgrave MacMillan, 2009.

44 Jan KELLER, Nejistota a di̊věra aneb K čemu je modernitě dobrá tradice, Praha: SLON, 2009. 
lované státem či samosprávou. Moment, kdy se organizace rozhodovaly, zda využít nabídky dotací, či nikoliv, lze označit za rozcestí, které pravděpodobně posléze determinovalo způsob jimi realizované kritické praxe.

Část z nich se rozhodla o dotace žádat, což ale bylo podmíněno řadou formalizovaných pravidel. Musely tedy projít procesem institucionalizace, aby naplnily požadavky zadavatelů. Aktivity původně vykonávané na základě potřeb klientů bylo třeba podřídit řadě podmínek a pravidel, které vyžadovaly dotační výzvy (personální, procedurální a provozní podmínky). Klíčovým momentem byl zejména rok 2006, kdy vstoupil v platnost Zákon o sociálních službách č. 108/2006. Sb. (s účinností od 1. ledna 2007) a vznikly Standardy kvality sociálních služeb. Původní relativní nezávislost a svoboda realizovat kritickou praxi byla do značné míry omezena pravidly dotačních výzev a kontrolou jejich dodržování ze strany zadavateli̊. Nad komunitní prací Českého západu a Vzájemného soužití začala převládat individuální práce s klienty, která vyplývá ze zákona o sociálních službách.

Hlavně v př́ipadě Českého západu ukazují výroční zprávy přesunutí priority na výkon sociálních služeb. Zatímco na počátku fungování této církevní organizace se v poslání organizace neobjevovala individuální sociální práce, ale především komunitní aktivity zaměřené na zvyšování participace romské komunity na veřejném dění, po zapojení do místní sítě sociálních služeb je ve výročních zprávách vždy na prvním místě uváděn výkon sociálních služeb. Ty ze svého zákonného vymezení (viz např. $\$ 2^{45}$ ) vnímají př́íčiny sociálních problémů jako individuální, stojí primárně na individuální práci s klienty, na jejich adaptaci na sociální prostředí a nezahrnují aktivity zaměřené na změnu sociálních struktur. Mezi základními činnostmi při poskytování sociálních služeb v $\$ 35$ je sice pod písmenem j) uvedena „pomoc při uplatňování práv, oprávněných zájmů a při obstarávání osobních záležitosti“', ale tato činnost je myšlena spíše ve vztahu k uplatňování práv ve vztahu k nejbližšímu sociálnímu prostředí, kterým je rodina či organizace, jejichž je, či by měla být, vyloučená osoba součástí. To se zrcadlí například v informačních systémech, do kterých se evidují výkony, kam lze jen obtížně zaznamenat jednání s politiky, psaní otevřených dopisů, medializaci situace, komunitní empowerment apod.

Z činnosti Českého západu nevymizely ani komunitní aktivity, ale ty se jeví s postupujícími roky jako stále více separované od majoritní společnosti. K vyslovení této hypotézy mě vede také osobní zkušenost s jedním z pracovníků této organizace na konferenci MPSV ke Světovému dni sociální práce v roce 2017. Ten tehdy v reakci na můj příspěvek o čtyřech zpo̊sobech realizace kritické praxe všem radostně avizoval, že koncepce této organizace doznala za poslední půlrok značné změny, protože se začala orientovat na Standardy kvality sociálních služeb a odklonila se od původního konceptu komunitní práce. Zdá se, že komunitní aktivity nesoucí znaky kritické praxe v organizaci stále přežívají, ale odehrávají se v nekonfliktním duchu a primárně na místní úrovni. Proces institucionalizace spuštěný snahou o zajištění stabilního financování tedy pravděpodobně vedl k přeskupení priorit organizace od komunitní práce zaměřené na potřeby vyloučených $\mathrm{k}$ individualizované práci. Opatrný ${ }^{46}$ tento trend označuje jako „podvazování charitativního úkolu církví, které se pragmaticky orientují na favorizované (rozuměj placené) sociální služby namísto pomoci těm, kterým ostatní nepomáhají.

Podobnou cestu institucionalizace zvolilo také Vzájemné soužití, i když jeho aktivity působí více

45 „Pomoc musí vycházet $\mathrm{z}$ individuálně určených potřeb osob, musí působit na osoby aktivně, podporovat rozvoj jejich samostatnosti, motivovat je k takovým činnostem, které nevedou k dlouhodobému setrvávání nebo prohlubování nepříznivé sociální situace, a posilovat jejich sociální začleňování.“

46 Michal OPATRNÝ, Charity a diakonie - poskytovatelé sociálních služeb nebo sekundární církevní struktura?, Caritas et veritas 1/2017, s. 92-97. 
ambivalentně. Na jedné straně zde přeživá kritická komunitní praxe hlavně v aktivitách ředitele a sociálního pracovníka Sri Kumara Viswanathana, ale na straně druhé zde fungují klasické individualisticky orientované sociální služby financované z dotací. Organizace se institucionalizovala, zároveň se však nevzdala aktivit směřujících k prosazování práv klientů. To ukazuje kauza Přednádraží, která měla pro organizaci i finanční dopady. Když v roce 2012 Stavební úřad centrálního ostravského obvodu Moravská Ostrava a Přívoz nařídil cca dvěma stovkám obyvatel vyklizení jejich domovů do dvaceti čtyř hodin kvůli nefunkční veřejné kanalizaci a havarijnímu stavu domů, postavila se organizace za část nájemníků, kteří odmítli ultimátum akceptovat. Vishwanathan také začal kritizovat město, že vědomě rozprodalo obecní majetek, místo aby se zabývalo sociálním bydlením pro chudé. Reakce městského obvodu na sebe nenechala dlouho čekat a uložila právní službě úřadu, aby prošetřila, zda jednání Vishwanathana „spočívající ve sdělování nepravdivých informací ohlednè situace v lokalitě Přednádraží a vzbuzující v obyvatelích domů na ulici Přednádraži rozhodnutí neuposlechnout nařízení stavebního úr̆adu, podle kterého měli povinnost objekt vyklidit, mohlo naplnit znaky skutkové podstaty trestného činu pomluvy a návodu k trestnému činu maření výkonu úřredního rozhodnutí “ ${ }^{77}$ Druhým odvetným krokem mohlo být následné vypovězení organizace ze dvou nebytových prostor, kde řadu let sídlila hlavní kancelář a sociálně-právní poradna (podrobněji viz Janebová a kol. ${ }^{48}$ ).

Vedle toho lze ve výročních zprávách Vzájemného soužití dohledat další aktivity zaměřené na změnu mezosystémů a makrosystémů, jako byla např́klad jednání s Ministerstvem kultury a s ministrem pro lidská práva o uzavření provozu firmy AGPI v Letech u Písku či iniciování urgentního setkání klíčových subjektů k řešení hrozby, že lidé v důsledku odmítavého stanoviska obcí neobdrží doplatky na bydlení. Tehdy (v roce 2015) se podařilo najít klíč k řešení, který vyjádřil ministr vnitra ve svém stanovisku, že tzv. Závazné stanovisko obcí „není závazné, a Ưřad práce mohl lidem doplatky na bydlení vyplatit. Tímto se podařilo dočasně zachránit 18 tisíc lidí před vystěhováním z ubytoven. Organizace se pak podílela společně s Platformou pro sociální bydlení a Svazem měst a obcí ČR na přípravě zákona o sociálním bydlení. Jiným úspěchem organizace bylo, že se podařilo motivovat městskou část Slezská Ostrava ke společnému kvalitnímu vzdělávání všech dětí bez rozdílu původu a etnicity. Institucionalizace tedy nezabránila Vzájemnému soužití ve výkonu kritické praxe, avšak organizace na vlastní kưži zažila sankce za „neposlušnost“. Je otázkou, jak je radikálnost jejích metod limitována strachem z opakování situace z roku 2012. V současné době se Vzájemné soužití angažuje proti zbourání osady Bedřiška, ale zatím nedošlo k užití radikálnějších metod.

Mimochodem, v podobné situaci finančního ohrožení se ocitly organizace Člověk v tísni a Poradna pro občanství / Občanská a lidská práva v Ústí nad Labem, když si dovolily otevřeným dopisem vyzvat Magistrát města Ústí nad Labem, „aby se zodpovědně postavil k řešení krizové situace lidí, kteří momentálně bydlí na uzavíraných ubytovnách v Klíšské a Purkyňově ulici. Jejich situace je beznadějná, zodpovědný zásah města je nezbytný. " Stalo se tak v rámci vystěhování dvou sociálních ubytoven v Ústí nad Labem v červnu 2018. Poté, co po novele Zákona o pomoci v hmotné nouzi č. 111/2006 Sb. s účinností od června 2017 vyhlásil Magistrát města Ústí nad Labem na svém úze-

47 (c) Ứad městského obvodu Moravská Ostrava a Př́voz, Právníci prošetř́i jednání a výroky pana Kumara (on-line), dostupné na: http:// www.moap.cz/ cs/o-moapu/aktualne/pravnici-prosetri-jednani-a-vyroky-pana-kumara-vishwanathana, aktualizace 2012, citováno dne 10. 7. 2013

48 Radka JANEBOVÁ - Marcela HUDEČKOVÁ - Romana ZAPADLOVÁ - Jana MUSILOVÁ, Př́iběhy sociálních pracovnic a pracovníků, kteří nemlčeli - Způsoby řešení dilemat, Sociální práce / Sociálna práca 2/2015, s. 23-37.

49 Martin KOVALČÍK, Ústecký magistrát musí lidem z uzavíraných ubytoven pomoci (on-line), Člověk v tísni, dostupné na: https://www. clovekvtisni.cz/co-delame/socialni-prace-v-cr/ustecky-kraj/ustecky-magistrat-musi-lidem-z-uzaviranych-ubytoven-pomoci-5095gp, aktualizace dne 6. 6.2018, citováno dne 2. 8. 2018. 
mí 22 oblastí se zvýšeným výskytem sociálně nežádoucích jevů a připravil obyvatele těchto oblastí o nárok na doplatek na bydlení, muselo se po uzavření dvou soukromých ubytoven vystěhovat cca 230 lidí (zejména rodiny s dětmi, senioři a invalidé). Město Ústí nad Labem se od řešení situace, kterou vyvolalo, distancovalo prohlášením, že nemá povinnost poskytnout náhradní byty, ale pouze povinnost sociální práce či sociálního poradenství. Proto požádalo poskytovatele sociálních služeb o provedení depistáže a zahájení sociální práce zaměřené na pomoc lidem ohroženým ztrátou bydlení. V situaci, kdy stát a město zapříčinily ztrátu jejich domovů, zbavily se odpovědnosti za řešení situace a odpovědnost přesunuly na sociální pracovníky (neziskových organizací i samosprávy). Ti měli politický problém řešit se zcela neadekvátním nástrojem, kterým je poradenství.

Tato neoliberální strategie bývá v zahraniční literatuře označována jako depolitizace vládnutí. ${ }^{50}$ Jejím cílem je delegovat původně politická témata $\mathrm{z}$ odpovědnosti státních orgánů na nepolitické výkonné složky, ideálně do neziskového sektoru. Dochází k převádění odpovědnosti původních státních domén na organizace občanské společnosti. Vina za sociální problémy pak může být připisována nejen chudým, ale také pověřeným subjektům, které nedisponují adekvátními nástroji $\mathrm{k}$ jejich řešení. $\mathrm{V}$ případě jejich selhání by nebyla odpovědnost přičítána celostátním ani regionálním politikům, ale sociálním pracovníkům. Například náměstek primátorky Ústí nad Labem Jiří Madar reagoval na otevřený dopis obou organizací tímto prohlášením: „Rozhodující by měly být výsledky. Zatím je to tak, že ani po letech pưsobení neziskovek čerpajících dotace z města nepřizpi̊sobivých obyvatel a př́jemců sociálních dávek neubývá. Informace o tom, kolika z nich pomohly neziskovky najít oficiální zaměstnání, nebo změnit zpưsob života, chybí. Bydlení v ubytovně pro řadu $z$ nich i pres dohled neziskovek přestalo být provizoriem, ale normou a problémy jen narůstají. $\mathrm{Na}$ to bude potřeba se zaměrit při vyhodnocení dotací a rozhodování o jejich dalším přidělování. "51 Ukazuje se, že institucionalizace, která je cestou k lepšímu finančnímu zajištění organizace, může mít i své stinné stránky, a to zejména podporu závislosti na donátorech, která může komplikovat získání těchto dotací v př́padě „neposlušnosti“.

\section{Cesta mimo institucionalizaci}

Druhá část organizací se na imaginárním rozcestí rozhodla pro trnitější cestu existence a institucionalizaci se nepodřídila. Toto rozhodnutí se jeví z provedeného výzkumu i z dokumentů na webových či facebookových stránkách jako záměrné, přičemž je odůvodňováno snahou o zachování nezávislosti na zadavatelích a obavou, že by čerpání dotací omezovalo paletu radikálnějších metod, kterých se dané organizace nechtějí vzdát. KRISA je platforma vyzývající na Facebooku k nejrůznějším radikálním akcím a jako taková má asi největší svobodu v užívání radikálních metod kritické sociální práce. Není na nikom finančně závislá a jediným rizikem může být nahlášení a zrušení profilu na Facebooku. ASLIDO realizovalo své aktivity přes menší projekty (především česko-norský grant, rakouská nadace) s tím, že využívalo dobrovolníky, či lidi na DPP. Ve výroční zprávě v roku 2016 uvádějí, že se záměrně rozhodli finance na další projekty nežádat. Svobodu využívat radikálnější metody práce jim může dávat skutečnost, že členové spolku nejsou existenčně závislí na finančních př́ímech $\mathrm{z}$ něj.

50 Matthew WOOD - Matthew FLINDERS, Rethinking Depoliticisation: Beyond the Governmental, Policy \& Politics 2/2014, s. 151-170.

51 () ROMEA.CZ, Kauza uzavřených ubytoven v Ústí končí. Lidé opustili tělocvičnu, magistrát útočí na neziskovky a chudé (on-line), dostupné na: http://www.romea.cz/cz/zpravodajstvi/domaci/kauza-uzavrenych-ubytoven-v-usti-konci-lide-opustili-telocvicnu-magistratutoci-na-neziskovky-a-chude, aktualizace dne 24. 7. 2018, citováno dne 2. 8. 2018. 
Nižší míra institucionalizace spojená s participací sociálně vyloučených lidí na druhou stranu zahrnuje riziko přehlížení, nespolupráce či označení za radikální subjekt zejména ze strany samosprávy. V prŕpadě $A S L I D O$ se tak stalo např́lklad v roce 2016, kdy s nimi odmítl o podobě sociálního bydlení na Ostravsku diskutovat nejen ostravský magistrát (konkrétně koordinátorka sociálního začleňování města Ostravy), ale paradoxně i ostravská pobočka Agentury pro sociální začleňování. Přestože zástupci obou organizací původně účast přislíbili, posléze se od diskuze distancovali. Dostal se jim totiž do rukou leták vyzývající lidi v bytové nouzi k participaci na diskuzi, což interpretovali jako „radikální požadavky jedné ze stran“. Součástí letáku bylo také Prohlášení o sociálním bydlení (prohlášení vzniklo společným úsilím skupin sdružujících lidi v bytové nouzi - Chceme bydlet $\mathrm{z}$ Prahy, Hnutí pro nové bydlení z Brna a Kruh naděje z Ostravy), které bylo také oběma organizacemi považováno za radikální. Mezi ony „radikální požadavky“ patřilo například finančně dostupné bydlení $\mathrm{v}$ bytech, které jsou hygienicky nezávadné a $\mathrm{v}$ technicky dobrém stavu, se základním vybavením jako např. s funkčním topením. V prohlášení byla dále požadována dostupnost bytů bez kaucí nebo bytů s podpůrnou sociální prací, která by hájila jejich zájmy jakožto nájemníků. ${ }^{52}$

Skutečnost, že méně formalizované organizace nemusí být brány ze strany samosprávy vážně, ukazuje i podobná zkušenost Konexí z roku 2018 ve výše popisované kauze vystěhování dvou ubytoven v Ústí nad Labem. Konexe jsou sice spolkem zapsaným 1. ledna 2014 u Krajského soudu v Ústí nad Labem, ale jinak fungují na neformální bázi a jejich členy jsou samotní Romové. $S$ představiteli samosprávy mají v podstatě stejnou zkušenost jako ASLIDO, když nebyli vystěhovávaní lidé z ubytoven přizváni na jednání o jejich budoucnosti. Na Facebooku Konexí to bylo komentováno těmito slovy: „Dozvěděli jsme se, že dnešní schuzka byla narychlo přeložena na jiné místo, poté, co se její organizátoři dozvěděli, že víme, kde se má odehrát. Asi se bojí, že by tam mohli prìijit lidé, o jejichž budoucnosti chtèjí jednat."

Výhodou trnitější cesty organizací realizujících kritickou praxi je finanční nezávislost, která umožňuje větší radikálnost akcí k prosazování práv lidí. Stát či samospráva na ně díky jejich neformálnímu fungování nemají finanční páku. To ale neznamená, že členové zmíněných spolků nemohou zažít odvetné akce. $V$ jejich př́ípadě se ale nejedná o důsledky finanční, ale o osočování na osobní rovině. $V$ př́ípadě Konexí byl oblíbeným objektem verbálních útoků jejich člen Miroslav Brož, který v kauze vystěhovaných ubytoven veřejně vystupoval s požadavkem, aby město řešilo dostupnost důstojného bydlení pro romské obyvatele, a kritizoval vyhlašování bezdoplatkových zón, kvůli kterým obyvatelé ubytoven přijdou o doplatek na bydlení. Za hlavní příčinu bytových problémů považoval etnickou segregaci ve městě Ústí. Také požadoval, aby město zajistilo účast osob postižených vystěhováním na jednáních $\mathrm{k}$ této věci. Odmítal přemístění vystěhovaných osob do okrajových lokalit Ostravy, kde jim bylo nabízeno ubytování bez vody a elektřiny, zato se štěnicemi. Posléze byl představiteli města označován jako aktivista, který odrazuje obyvatele ubytoven od spolupráce se sociálními pracovníky města a neziskových organizací. Náměstek Madar se o něm vyjádřil takto: „Aktivista Brož ztěžuje zaměstnankyním magistrátu a obvodů jejich práci na končicích ubytovnách. Nabádá ubytované, aby si bydlení nehledali, a napadá mèsto tak, že zvažujeme podání trestního oznámení. Vưbec mu nejde o pořádek ve městě, klid občanů, ale jen o zviditelnění. "53

52 C Eliška ČERNÁ, Př́liš radikální? (on-line), A2larm, dostupné na: http://a2larm.cz/2016/09/prilis-radikalni/, aktualizace dne 29. 9. 2016, citováno dne 10. 10. 2018.

53 ○ Zuzana MENDLOVÁ, Ústecký magistrát selhal v integraci Romů, prohlašuje místní aktivista (on-line), iDNES, dostupné na: https:// usti.idnes.cz/aktivista-miroslav-broz-predlice-romove-usti-nad-labem-ubytovny-phl-/usti-zpravy.aspx?c=A180622_124246_ustizpravy_vac2, aktualizace dne 24. 6. 2018, citováno dne 10. 10. 2018. 
Organizace, které dobrovolně vzdorují institucionalizaci, mají tedy díky finanční nezávislosti větší prostor pro kritičtější akce, ale zároveň nejsou ani jejich členové chráněni před vyhrožováním na osobní rovině či trestními oznámeními. Lze také předpokládat, že kritická angažovanost v neinstitucionalizované organizaci může mít následky v jiných aspektech osobního života. I aktivistická sociální pracovnice či pracovník se musí nějak živit, takže existuje reálné riziko, že pokud pracuje v oblasti sociálních služeb či veřejné správy, odveta se přesune na organizaci, v níž jsou zaměstnáni, příp. do osobního života. Pokud probíhá neplacená kritická praxe souběžně s placeným zaměstnáním, je taková situace velmi vyčerpávající, dlouhodobě neudržitelná a zasahuje do rodinného života. Existuje tedy riziko, že tyto aktivity časem vyšumí vlivem únavy ideových leaderů.

Zdá se, že Kentauří stát má dobře promyšleny strategie, jak pacifikovat kritickou praxi. Institucionalizovaní poslouchají ze strachu o peníze pro svou organizaci, zatímco neinstitucionalizované postačí ponechat napospas jejich potřebě existenčně se zajistit (př́ípadně jim občas pohrozit) a časem přstanou zlobit také.

\section{Závěr a diskuze k otázce, jak realizovat kritickou praxi v rámci Kentauřrího státu}

V příspěvku jsem předložila hypotézu, že organizace založené na kritické praxi stály či stojí před dilematem, zda formalizovat svou existenci, vstoupit do institucionalizovaného systému sociálních služeb a zajistit si relativní finanční stabilitu s rizikem tlaků na utlumování kritické praxe, nebo zůstat deformalizovanými, což s sebou nese finanční nejistotu, ale současně poskytuje větší svobodu vykonávat takovouto praxi v zájmu klientů. Do tohoto dilematu mohou vstupovat ještě další proměnné.

Přetrvávající kritická praxe Kumara Vishwanathana může ukazovat, že ani institucionalizovaná sociální práce nemusí na aktivismus rezignovat. Jedním $\mathrm{z}$ důvodů by mohla být osobnost tohoto sociálního pracovníka, který se angažuje ve vládních a mezinárodních institucích prosazujících lidská práva, je ověnčen řadou cen za svou práci a má kontakty na významné politiky s celorepublikovou působností. Jeho sociální kapitál tedy může snižovat obavy z možných sankcí.

Vyhrožování ústeckého náměstka Madara organizaci Člověk v tísni se také může minout účinkem, vzhledem k velikosti a politické síle této organizace. Možná může být cestou k emancipaci samotné sociální práce fúzování organizací do větších sociálních konglomerátů, které budou mít v lokálních oblastech větší sílu a nezávislost a na celostátní úrovni získají prostor i pro politický lobbing. Zajímavé ovšem bude sledovat v ústeckém kontextu osud Poradny pro občanství / Občanská a lidská práva, která takovou politickou silou nedisponuje.

Prosazování kritické praxe v institucionalizovaných organizacích může nahrávat také systém financování, který je vícezdrojový a ne zcela decentralizovaný. Pokud by došlo k decentralizaci a subsidiarizaci financování výhradně na úroveň obcí, mohlo by to silně utlumit kritický potenciál sociální práce zejména na místní úrovni. Díky určité odtažitosti krajského, případně státního financování od lokálních sociálních konfliktů lze stále kompenzovat finanční odvety samospráv z centralizovanějších zdrojů. Na čím vyšší úrovni odveta za aktivismus probíhá, tím je více viditelná a politicky rizikovější. Paradoxně tak může být větší centralizace financování v zájmu sociálně vyloučených lidí v konkrétních místních komunitách.

Cestou ke kritické praxi u institucionalizovaných organizací se tedy zdá být budování sociálního kapitálu a sítí ze strany sociálních pracovnic a pracovníků těchto organizací, spojování do větších sociálních holdingů a podpora centralizace financování. 


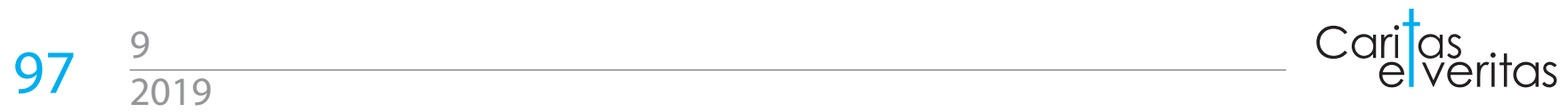

V prŕpadě subjektů, které se neinstitucionalizovaly, se jako cesta př̌žití jeví ústup od izolovanosti kritické praxe a spojování do podpůrných sítí, které budou prosazovat zájmy „neoliberálních delikventü“ společně, a to včetně participace samotných chudých. Vzorem mủže být sít SWAN (The Social Work Action Network), která se dlouhodobě zabývá dopady ekonomické politiky na sociální práci nejen ve Velké Británii, ale také v Irsku, Řecku či Španělsku. Sdružuje sociální pracovnice, lidi z akademické sféry, studující a uživatele služeb. Tyto všechny spojují obavy o osud sociální práce $\mathrm{v}$ ére neoliberalismu, která je devalvována sociálními škrty, úsporami a podfinancováním, vyváděním peněz z veřejné sféry a privatizací, zaváděním tržních mechanismů a konkurence, manažerismem a oslabováním solidarity.

\section{Kontakt}

Mgr. Radka Janebová, Ph.D.

Univerzita Hradec Králové

Filozofická fakulta, Ústav sociální práce

Víta Nejedlého 573, 50000 Hradec Králové

radka.janebova@uhk.cz 